\title{
HPLC Analysis of Ascorbic Acid (Vitamin C)
}

\section{Hideharu Shintani}

Chuo University, School of Science, 1-13-27, Kasuga Bunkyo 112-0003 Tokyo, Japan

\section{Introduction}

Although several indirect methods are available for measurement of ascorbic acid (AA, Vitamin C), the specificity is generally poor. In addition, for accurate evaluation of vitamin $\mathrm{C}$ status, dehydroascorbic acid (DHAA), the oxidation product of AA should also be measured simultaneously. Although direct measurement of DHAA is possible, the indirect method [1] described uses highly sensitive HPLCelectrochemical detector (ECD) equipment [2-6]. ECD is quite sensitive with relative lower oxidation-reduction potential compounds, i.e., less than $1000 \mathrm{mV}$. Based on these reported methods [2-6], total AA is estimated after the reduction of DHAA to AA and DHAA is then calculated from the difference between total AA and free AA (reduced form) originally present in the sample.

\section{Protocol}

\section{Sample preparation}

1. Mix plasma $(25 \mu \mathrm{L})$ with metaphosphoric acid $(5 \%, 225 \mu \mathrm{L})$ containing desferrioxamine mesylate (Sigma; $20 \mathrm{mM}$ )

2. Centrifuge at $3000 \mathrm{~g}$ for $10 \mathrm{~min}$.

3. Isolate supernatant for measurement of reduced and total AA.

\section{Measurement of reduced AA}

1. Mix supernatant $(75 \mu \mathrm{L})$, distilled water $(50 \mu \mathrm{L})$, and metaphosphoric acid $(50 \%, 25 \mu \mathrm{L})$.

2. Centrifuge at $3000 \mathrm{~g}$ for $10 \mathrm{~min}$.

3. Isolate supernatant $(5 \mu \mathrm{L})$ for direct HPLC injection.

\section{Measurement of total AA}

1. Mix supernatant $(75 \mu \mathrm{L})$, dithiothreitol (DTT; $10 \mathrm{mM}, 25 \mu \mathrm{M}$, and $\mathrm{K}_{2} \mathrm{HPO}_{4}(40 \mathrm{mM}, 25 \mu \mathrm{L}$; to maintain the $\mathrm{pH}$ of the mixture at 6.8).

2. React for $20 \mathrm{~min}$ at room temperature in the dark.

3. Add metaphosphoric acid $(50 \%, 25 \mu \mathrm{L})$.

4. Centrifuge at $3000 \mathrm{~g}$ for $10 \mathrm{~min}$.

5. Isolate supernatant $(5 \mu \mathrm{L})$ for direct HPLC injection.

HPLC was performed with an lrika Instruments (Kyoto, Japan) $\sum$-871 chromatograph equipped with a $250 \mathrm{~mm} \times 4 \mathrm{~mm}$ i.d. lrica RP18T (ODS) column and lrika Amperometric S-875 ECD with glossy carbon working electrode set at $700 \mathrm{mV}$ relative to $\mathrm{Ag} / \mathrm{AgCI}$. The mobile phase was $0.2 \mathrm{M} \mathrm{KH}_{2} \mathrm{PO}_{4}-\mathrm{H}_{2} \mathrm{PO}_{4}(\mathrm{pH}$ 3.0) containing $50 \mu \mathrm{M}$ EDT A.

The amount of DHAA is total AA minus reduced AA.

\section{Discussion}

Although the ratio of DHAA to AA is reported to be constant for whole blood stored at $4^{\circ} \mathrm{C}$ for $6 \mathrm{~h}, \mathrm{AA}$ in plasma or serum is highly labile and readily oxidized to DHAA and subsequently to diketogulonic acid. To prevent oxidation of AA in plasma samples, add desferrioxamine. In the presence of $20 \mathrm{mM}$ desferrioxamine, more than $98 \%$ of the AA content is preserved when plasma is stored at $4^{\circ} \mathrm{C}$ in the dark for 6 $\mathrm{h}$. Dithiothreitol is used as the reductant for DHAA, because it is the most suitable at a neutral $\mathrm{pH}[7,8]$. The recovery of DHAA added to plasma is $98.9 \%$ in the presence of $10 \mathrm{mM}$ dithiothreitol at $\mathrm{pH} 6.8$. This reaction was complete within $20 \mathrm{~min}$ at $25^{\circ} \mathrm{C}$ in the dark.

\section{References}

1. Ogihara T, Kim HS, Hirano K, Imanishi M, Ogihara H, et al. (1998) Oxidation products of uric acid and ascorbic acid in preterm infants with chronic lung disease. Biol Neonate 73: 24-33.

2. Iriyama K, Yoshiura M, Iwamoto T, Ozaki Y (1984) Simultaneous determination of uric and ascorbic acids in human serum by reversed-phase high-performance liquid chromatography with electrochemical detection. Anal Biochem 141: 238243.

3. Khan A, Khan MI, Iqbal Z, Shah Y, Ahmad L, et al. (2011) A new HPLC method for the simultaneous determination of ascorbic acid and aminothiols in human plasma and erythrocytes using electrochemical detection. Talanta 84: 789-801.

4. Li X, Franke AA (2009) Fast HPLC-ECD analysis of ascorbic acid dehydroascorbic acid and uric acid. J Chromatogr B Analyt Technol Biomed Life Sci 877: 853-856.

5. Umegaki K, Inoue K, Takeuchi N, Higuchi M (1994) Improved method for the analysis of ascorbic acid in plasma by high-performance liquid chromatography with electrochemical detection. J Nutr Sci Vitaminol (Tokyo) 40: 73-79.

6. Watson DG, Iqbal Z, Midgley JM, Pryce-Jones H, Morrison L, et al. (1993) Measurement of ascorbic acid in human aqueous humour and plasma and bovine aqueous humour by high-performance liquid chromatography with electrochemical detection. J Pharm Biomed Anal 11: 389-392.

7. Margolis SA, Davis TP (1988) Stabilization of ascorbic acid in human plasma and its liquid-chromatographic measurement. Clin Chem 34: 2217-2223.

8. Okamura M (1980) An improved method for determination of L-ascorbic acid and L-dehydroascorbic acid in blood plasma. Clin Chim Acta 103: 259-268.

*Corresponding author: Hideharu Shintani, Chuo University, School of Science 1-13-27, Kasuga Bunkyo 112-0003 Tokyo, Japan, Tel: +81425922336; E-mail shintani@mail.hinocatv.ne.jp

Received January 28, 2013; Accepted May 15, 2013; Published May 18, 2013

Citation: Shintani H (2013) HPLC Analysis of Ascorbic Acid (Vitamin C). Pharm Anal Acta 4: 234. doi:10.4172/2153-2435.1000234

Copyright: (c) 2013 Shintani H. This is an open-access article distributed unde the terms of the Creative Commons Attribution License, which permits unrestricted use, distribution, and reproduction in any medium, provided the original author and source are credited. 